\title{
Chromosomal evidence of population subdivision in the freshwater fish Leporinus elongatus in the Upper Paraná River basin
}

\author{
Wagner Franco Molina ${ }^{1}$, Oscar Shibatta ${ }^{2}$ and Pedro Manoel Galetti Jr. ${ }^{3}$ \\ ${ }^{1}$ Departamento de Biologia Celular e Genética, Centro de Biociências, \\ Universidade Federal do Rio Grande do Norte, Natal, RN, Brazil. \\ ${ }^{2}$ Departamento de Biologia Animal e Vegetal, Universidade Estadual de Londrina, Londrina, PR, Brazil. \\ ${ }^{3}$ Departamento de Genética e Evolução, Universidade Federal de São Carlos, São Carlos, SP, Brazil.
}

\begin{abstract}
Cytogenetic analyses performed in populations of the Neotropical freshwater fish Leporinus elongatus of the Upper Paraná River basin showed a chromosome polymorphism involving heterochromatic segments of the nucleolar organizing pair in this species. The NOR-bearing chromosome pair was characterized by two phenotypes identified by the absence $\left(C^{1}\right)$ or presence $\left(C^{2}\right)$ of a heterochromatic segment located in an interstitial position of the long arm in this pair. The meiotic segregation of these variations results in three distinct cytotypes, $C^{1} C^{1}, C^{1} C^{2}$ and $C^{2} C^{2}$. Both populations were in Hardy-Weinberg equilibrium. Sex-related cytotype divergence was identified and multivariate analyses revealed that the $C^{2} C^{2}$ individuals presented morphometric differentiation relative to body height in relation to the other cytotypes. A chromosome differentiation and a cytotype proportion difference observed between both populations suggest the occurrence of population subdivision within this species along the Upper Paraná River basin. These findings might contribute to the knowledge of the population biology of this fish and for its conservation.

Key words: Characiformes, Anostomidae, heterochromatin, chromosome polymorphism.
\end{abstract}

Received: September 1, 2006; Accepted: May 14, 2007.

The ever-growing and disordered anthropic activities in the different Brazilian hydrographic systems have been causing grave concern among researchers with respect to the possibility of extinction of large sets of fish species in many localities. Destruction, alteration and fragmentation of natural environments can cause an enormous loss of biodiversity, including at the genetic level (Avise, 1996). It is often claimed that genetic diversity is fundamental for the adaptation and speciation of a taxon (Hutchinson et al., 2003) and populations that have suffered severe size reductions or bottlenecks are more likely to become extinct (Frankham, 1996).

Moreover, because both genetically or phenotypically divergent populations should be considered independent evolutionary taxa (Mesquita et al., 2005), the geographic delimitation of a particular species and the amount of genetic variability within and between its populations are essential in the determination of appropriate geographical scales for conservation and in the determination of the management strategies to be adopted (Palumbi,

Send correspondence to Pedro M Galetti Jr. Departamento de Genética e Evolução, Universidade Federal de São Carlos, Caixa Postal 676, 13565-905 São Carlos, SP, Brazil. E-mail: galettip@ power.ufscar.br.
2003). This is particularly important in freshwater fish which display conspicuous migratory behavior and can be believed to comprise large and single population in a hydrographic system (e.g., Revaldaves et al., 1997).

Little is known about the genetic structure of Brazilian freshwater fishes. Recently, molecular markers have been used for genetic structure analyses in different migratory fish species (e.g., Martins et al., 2003; Hatanaka et al., 2006) but the results are still controversial. The occurrence of single and large population was claimed to explain the results obtained for Prochilodus lineatus from Upper Paraná River (Revaldaves et al., 1997) and Pseudoplatystoma fasciatum from the Bolivian basin (Coronel et al., 2004) for instance, while population subdivisions along a single hydrographic system were reported in Prochilodus argenteus from the São Francisco River (Hatanaka et al., 2006) and Pseudoplatystoma corruscans from the Paraná River (Sekine et al., 2002). All these studies employed highly polymorphic molecular marker systems. In contrast, most of cytogenetic studies focus on general pattern descriptions, including chromosome banding of a particular species or on an evolutionary approach of related species. Chromosome polymorphism have been reported in fish (e.g., Giuliano-Caetano and Bertollo, 1988; Jankun and Ráb, 1997; 
Jorge and Moreira-Filho, 2000) but rarely studied in the population context (Turner et al., 1985).

In this work the occurrence of a heterochromatin polymorphism in the Neotropical freshwater species Leporinus elongatus inhabiting a single major hydrographic system was able to document the occurrence of population subdivision within this species. In addition, the chromosome polymorphism was related to a set of morphological features.

Cytogenetic analysis. Twenty-eight $L$. elongatus specimens (17 males and 11 females) from the MogiGuaçú River sampled in the municipality of Pirassununga (SP) and 53 (43 males and 10 females) from the Paranapanema River collected near the municipality of Ourinhos (SP), both rivers belonging to the Upper Paraná basin (Southeastern Brazil), were analyzed. The chromosome preparations were obtained from anterior kidney tissue by direct tissue dissociation (Bertollo et al., 1978) or by short term culture (Fenocchio et al., 1991). The mitotic chromosomes were submitted to C-banding (Sumner, 1972) using Giemsa staining or the 4'-6-diamidine-2-phenylindole fluorochrome (C/DAPI banding). Ag-NOR sites were stained according to Howell and Black (1980). Replication bands were obtained through the in vitro incorporation of the 5-Brdu base analogue (Giles et al., 1988).

The populational chromosome differentiation was investigated based on the Wright fixation index Fst (Weir and Cockerham, 1984) implemented in the computer program FSTAT 2.9.3.2 (Goudet, 2001). The index was used to quantify the proportion of genetic variation that lies between subpopulations within the total population. Chisquare test performed with the software BIOESTAT 3.0 (Ayres et al., 2003) was also used to compare cytotype frequency difference between populations, as well as between sexes. Hardy-Weinberg equilibrium was calculated manually.

Morphometric analysis. Body measurements of 23 morphological features were performed on 81 specimens of L. elongatus (Table 1) using the truss net method (Strauss and Bookstein, 1982). Size-free canonical discriminant analysis (Reis et al., 1990) was performed using the SASPC statistical software (SAS Institute Inc., 1988) to estimate differences within and between stocks. Through the projection of the individual scores on the canonical axes of a bidimensional graph, this analysis allows to view the morphological similarity patterns between the individuals of these groups. It is also possible to obtain the discriminant features of each group.

The karyotype of L. elongatus of both the MogiGuaçú and the Paranapanema populations had $2 n=54$ chromosomes for both sexes, with ZW sex chromosomes characterizing the female karyotype, as already reported by Galetti et al. (1981). Most chromosomes are slightly heterochromatic in their telomeric regions, with some pairs
Table 1 - Characters used in the canonical variate analysis of Leporinus elongatus from the Mogi-Guaçú and Paranapanema Rivers. Weight of the morphometric variables in the first (CV1) and second canonical (CV2) axes of the combined samples.

\begin{tabular}{lcccc}
\hline Measured character & CV1 & p & CV2 & p \\
\hline snout to pectoral fin & -0.25 & 0.0289 & 0.23 & 0.0411 \\
length of head & -0.24 & 0.0326 & 0.03 & 0.8106 \\
pectoral fin to head & -0.01 & 0.9178 & 0.14 & 0.2232 \\
dorsal pectoral distance & 0.22 & 0.0534 & 0.16 & 0.1598 \\
pectoral pelvic distance & -0.33 & 0.0037 & 0.10 & 0.4018 \\
head to dorsal fin origin & -0.06 & 0.6302 & 0.34 & 0.0022 \\
head to pelvic fin & 0.08 & 0.4825 & 0.11 & 0.3264 \\
dorsal origin to pelvic fin & 0.36 & 0.0013 & -0.03 & 0.8088 \\
dorsal base length & 0.09 & 0.4472 & -0.08 & 0.5059 \\
dorsal origin to anal origin & 0.42 & 0.0001 & -0.36 & 0.0015 \\
pelvic fin to last dorsal fin ray & 0.37 & 0.0008 & 0.11 & 0.3582 \\
pelvic fin to anal origin & 0.30 & 0.0072 & 0.13 & 0.2683 \\
anal origin to the last dorsal fin ray & 0.49 & 0.0001 & -0.28 & 0.0123 \\
last dorsal ray to adipose fin & 0.19 & 0.1033 & -0.11 & 0.3431 \\
last dorsal ray to the last anal ray & 0.49 & 0.0001 & -0.11 & 0.3337 \\
anal fin origin to adipose fin & -0.22 & 0.0588 & -0.07 & 0.5520 \\
anal fin base length & -0.11 & 0.3581 & 0.02 & 0.8447 \\
adipose fin to last anal ray & 0.05 & 0.6522 & -0.007 & 0.9488 \\
adipose fin to superior caudal base & -0.25 & 0.0291 & 0.08 & 0.4913 \\
adipose fin to inferior caudal base & -0.33 & 0.0034 & -0.17 & 0.1426 \\
last anal ray to superior caudal base & -0.13 & 0.2699 & -0.10 & 0.4066 \\
last anal ray to inferior caudal base & -0.18 & 0.1148 & -0.03 & 0.8148 \\
least depth caudal peduncle & -0.19 & 0.0917 & -0.29 & 0.0093 \\
\hline
\end{tabular}

presenting centromeric and/or pericentromeric blocks (Figure 1).

The nucleolar organizing region was detected in the telomeric portion of the long arm of a large submetacentric pair (\# 5) (Figure 1). The NOR-bearing chromosomes were observed in two variant forms denominated hereafter as $\mathrm{C}^{1}$ and $\mathrm{C}^{2}$. The $\mathrm{C}^{1}$ variant had positive C-bands in the telomeric region of its short and long arm, in the latter coinciding with a secondary constriction. Besides the characteristics present in the $C^{1}$ phenotype, the larger $C^{2}$ variant also presented a large C-banded and late-replicating heterochromatic block observed in the interstitial portion of the long arm (Figure 1). This heterochromatin-related polymorphism found here was already previously described in $L$. elongatus (Köehler et al., 1997; Molina et al., 1998), and enables the identification of two phenotypes of the NORbearing chromosomes differing in the absence $\left(\mathrm{C}^{1}\right)$ or presence $\left(\mathrm{C}^{2}\right)$ of a conspicuous heterochromatic segment interstitially positioned in the long arm of this chromosome. The comparison of these phenotypes with the nucleolar chromosome of $L$. friderici, considered the basic type for the group (Galetti et al., 1984), shows an apparently higher 


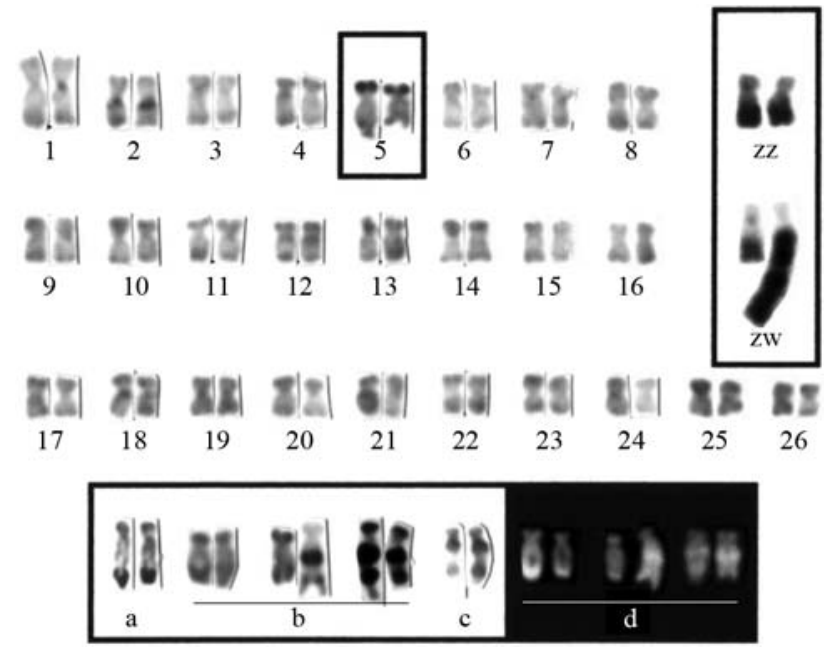

Figure 1 - C-banding patterns in a somatic metaphase of Leporinus elongatus. In the lower frame the three variants of the nucleolar organizing pair $\left(5^{\text {th }}\right)$ found in this species, (a), Ag-NOR site in the $\mathrm{C}^{1} \mathrm{C}^{1}$ variant, (b), C-banded $C^{1} C^{1}, C^{1} C^{2}$ and $C^{2} C^{2}$ cytotypes, (c), replication bands in the $\mathrm{C}^{2} \mathrm{C}^{2}$, and (d) C/DAPI-banded $\mathrm{C}^{1} \mathrm{C}^{1}, \mathrm{C}^{1} \mathrm{C}^{2}$ and $\mathrm{C}^{2} \mathrm{C}^{2}$ cytotypes.

similarity of $L$. friderici with the $\mathrm{C}^{1} \mathrm{C}^{1}$ cytotype than with the $\mathrm{C}^{2} \mathrm{C}^{2}$ and it is suggested that the $\mathrm{C}^{2}$ is a derived phenotype.

The three possible combinations of these variants, $C^{1} C^{1}, C^{1} C^{2}$ and $C^{2} C^{2}$ (Figure $1 b$ ), were found in both sexes (Table 2). $C^{1} C^{1}$ and $C^{1} C^{2}$ were the most frequent cytotypes in both populations. The presence of a large heterochromatic block inside the euchromatic segment on the long arm of the chromosome of $\mathrm{C}^{2}$ phenotype could promote negative position effects or changes in the gene regulatory processes which could lead to physiological and morphological changes in $\mathrm{C}^{2} \mathrm{C}^{2}$ individuals. However, both populations were in Hardy-Weinberg equilibrium (Mogi-Guaçú, $\chi^{2}=0.47, \mathrm{DF}=1 ; 0.95>\mathrm{p}>0.80 ;$ Paranapanema, $\left.\chi^{2}=1.01, \mathrm{DF}=1 ; 0.30>\mathrm{p}>0.20\right)$ suggesting the occurrence of neutral effects of these cytotypes. Although $\mathrm{C}^{1}$ was observed relatively more frequent in both populations, its frequency only was evidently higher in the Paranapanema population. There was no significant cytotype frequency difference between sexes within each population, but it was significant when both populations were pooled $\left(\chi^{2}=5.754\right.$, $\mathrm{DF}=2, \mathrm{p}=0.05)$. The biological significance of this sex-related divergence is still an open question, although a sampling bias comprising three times more males than females could not be discarded.

In contrast, the morphometric multivariate analysis revealed that the first canonical axis retains $61.6 \%$ of the total variance of the original data matrix, allowing the discrimination of the $\mathrm{C}^{2} \mathrm{C}^{2}$ individuals from the remaining ones (Figure 2). The particular morphometric characters for this cytotype refer to the distance from the dorsal-fin origin to anal-fin origin, the distance from the pelvic fin to last dorsal-fin ray, the distance from the anal-fin origin to the
Table 2 - Chromosome variants $\left(\mathrm{C}^{1}\right.$ and $\left.\mathrm{C}^{2}\right)$ in both sexes $(\mathrm{F}$, females and $\mathrm{M}$, males) detected in Leporinus elongatus in both studied populations. $\mathrm{N}=$ number of individuals; $f=$ frequency

\begin{tabular}{lcrrrrr}
\hline Population & \multirow{2}{*}{ Sex } & \multicolumn{3}{c}{$\mathrm{N}$} & \multirow{2}{*}{$f\left(\mathrm{C}^{1}\right)$} & $f\left(\mathrm{C}^{2}\right)$ \\
\cline { 3 - 5 } & & $\mathrm{C}^{1} \mathrm{C}^{1}$ & $\mathrm{C}^{1} \mathrm{C}^{2}$ & $\mathrm{C}^{2} \mathrm{C}^{2}$ & & \\
\hline Mogi-Guaçú & $\mathrm{F}$ & 2 & 7 & 2 & 0.50 & 0.50 \\
& $\mathrm{M}$ & 8 & 6 & 3 & 0.65 & 0.35 \\
& sum & 10 & 13 & 5 & 0.59 & 0.41 \\
\hline Paranapanema & $\mathrm{F}$ & 5 & 5 & 0 & 0.75 & 0.25 \\
& $\mathrm{M}$ & 28 & 11 & 4 & 0.77 & 0.23 \\
& sum & 33 & 16 & 4 & 0.77 & 0.23 \\
\hline
\end{tabular}

last dorsal-fin ray, as well as the distance from the last dorsal-fin ray to the last anal-fin ray. These variables are related to the fish body height and indicate a body divergence of the $\mathrm{C}^{2} \mathrm{C}^{2}$ individuals comparing to the other cytotypes.

The cytotype frequencies between populations were very close to being significantly different when using the Chi-square test $\left(\chi^{2}=5.535, \mathrm{DF}=2, \mathrm{p}=0.06\right)$ and they differed significantly when Fst was used $(F s t=0.0648$, $\mathrm{p}=0.05$ ), suggesting a population subdivision within this species. These results were concordant with a previous study in this species which detected mtDNA haplotype divergence between representatives of different populations (Martins et al., 2003). Due to the great hydroelectric potential of the Upper Paraná River basin, the physical continuity between the Mogi-Guaçú and Paranapanema Rivers is partially blocked due to several dams constructed in the past 50 years between the two collection sites. A genetic drift

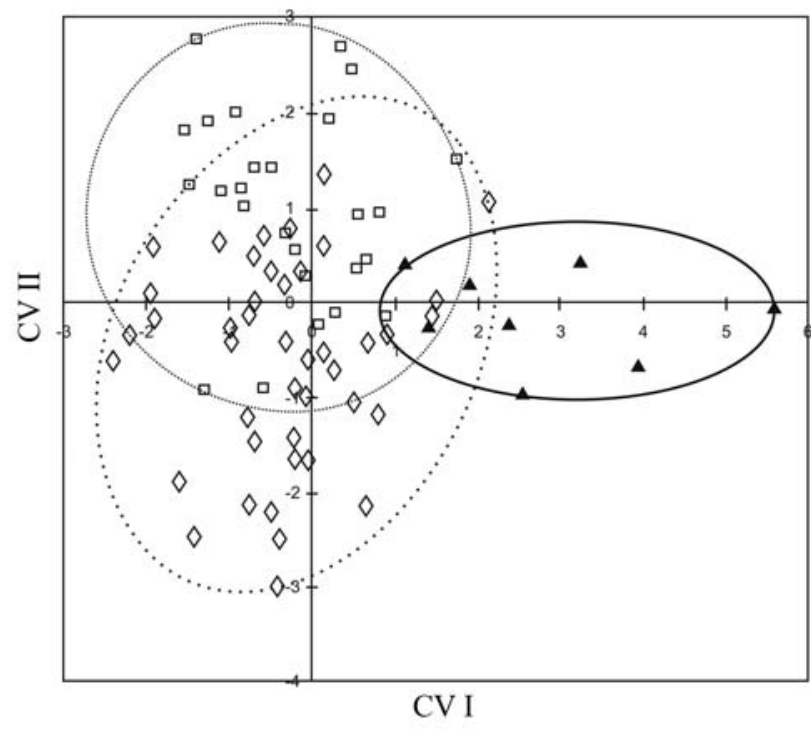

Figure 2 - Projection of the individual scores obtained in a size-free canonical discriminant analysis of 23 morphological body features of the combined samples of Leporinus elongatus of the Mogi-Guaçú and Paranapanema populations. The diamonds $(\diamond)$ correspond to cytotype $C^{1} C^{1}$, squares $(\square)$ to cytotype $C^{1} C^{2}$ and the dark triangles $(\mathbf{\Lambda})$, to $C^{2} C^{2}$. 
caused by the dam constructions and a reduced or absent gene flow between these currently isolated populations could be promoting the observed chromosome divergence. However, because their potentially high effective population size and considering that no more than fifty generations have passed since the dam constructions, the detection of genetic drift effects under such conditions would be unlikely. Thus, a chromosome divergence that had already occurred before the dam constructions can not be rejected.

The detection of a differential occurrence of three cytotypes between two recently isolated populations indicating a population subdivision in L. elongatus in the Upper Paraná River basin might constitute important information to better understand the population biology of this fish and for its conservation.

\section{Acknowledgments}

The authors are grateful to João Henrique Pinheiro Dias for the facilities during fish collection in the Paranapanema River and Reinaldo O Alves de Brito for significant suggestions. This work was supported by the Coordenação de Aperfeiçoamento de Pessoal Docente do Ensino Superior (CAPES) and Conselho Nacional de Desenvolvimento Científico e Tecnológico (CNPq).

\section{References}

Avise JC (1996) Space and time as axes in intraspecific phylogeography. In: Huntley B, Cramer W, Morgan AV, Prentice $\mathrm{HC}$ and Allen JRM (eds) Past and Future Environmental Changes: The Spatial and Evolutionary Responses of Terrestrial Fauna. Springer-Verlag, New York, pp 381-388.

Ayres M, Ayres Jr M, Ayres DL and Santos AS (2003) Bioestat, v. 3.0. Sociedade Civil Mamirauá, Belém.

Bertollo LAC, Takahashi CS and Moreira-Filho O (1978) Cytotaxonomic considerations on Hoplias lacerdae (Pisces, Erythrinidae). Braz J Genet 1:103-120.

Coronel JS, Maes JE, Claus S, Vandamme PA and Volckaert FAM (2004) Differential population history in the migratory catfishes Brachyplatystoma flavicans and Pseudoplatystoma fasciatum (Pimelodidae) from the Bolivian Amazon assessed with nuclear and mitochondrial DNA markers. J Fish Biol 65:859-868.

Fenocchio AS, Venere PC, Cesar ACG, Dias AL and Bertollo LAC (1991) Short term culture from solid tissues of fishes. Caryologia 44:161-166.

Frankham R (1996) Relationship of genetic variation to population size in wildlife. Conserv Biol 10:1500-1508.

Galetti Jr PM, Foresti F, Bertollo LAC and Moreira-Filho O (1981) Heteromorphic sex chromosomes in three species of the genus Leporinus (Pisces, Anostomidae). Cytogenet Cell Genet 29:138-142.

Galetti Jr PM, Foresti F, Bertollo LAC and Moreira-Filho O (1984) Characterization of eight species of Anostomidae (Cypriniformes) fish on the basis of the nucleolar organizing region. Caryologia 37:401-406.
Giles V, Thode G and Alvarez MC (1988) Early replication bands in two scorpion fishes, Scorpaena porcus and S. notata (order Scorpaeniformes). Cytogenet Cell Genet 47:80-83.

Giuliano-Caetano L and Bertollo LAC (1988) Karyotype variability in Hoplerythrinus unitaeniatus (Characiformes, Erythrinidae). I. Chromosome polymorphism in the Rio Negro population (Manaus, State of Amazonas). Braz J Genet 11:299-306.

Goudet J (2001) FSTAT, a program to estimate and test gene diversities and fixation indices, v. 2.9.3. http:// www.unil.ch /izea/softwares/fstat.html.

Hatanaka T, Henrique-Silva F and Galetti Jr PM (2006) Population substructuring in a migratory freshwater fish Prochilodus argenteus (Characiformes, Prochilodontidae) from the São Francisco River. Genetica 126:1-7.

Howell WM and Black A (1980) Controlled silver staining of nucleolus organizer regions with protective colloidal developer: 1- step method. Experientia 36:1014-1015.

Hutchinson WF, van Oosterhout C, Rogers SI and Carvalho GR (2003) Temporal analysis of archived samples indicates marked genetic changes in declining North Sea cod (Gadus morhua). Proc R Soc 270:2125-2132.

Jankun M and Ráb P (1997) Multiple polymorphism of chromosome n. 1 in the karyotype of whitefish, Coregonus lavaretus (Salmonidae) from lake system Saimaa, Finland. Caryologia 50:185-195.

Jorge LC and Moreira-Filho O (2000) Cytogenetic studies on Apareiodon affinis (Pisces, Characiformes) from Paraná river basin: Sex chromosomes and polymorphism. Genetica 109:267-273.

Köehler MR, Dehm D, Guttenbach M, Nanda I, Haaf T, Molina WF, Galetti Jr PM and Schmid M (1997) Cytogenetics of the genus Leporinus (Pisces, Anostomidae). 1. Karyotype analysis, heterochromatin distribution and sex chromosomes. Chromosome Res 5:12-22.

Martins C, Wasko AP, Oliveira C and Foresti F (2003) Mitochondrial DNA variation in wild populations of Leporinus elongatus from the Paraná River Basin. Genet Mol Biol 26:33-38.

Mesquita N, Hanfling B, Carvalho GR and Coelho MM (2005) Phylogeography of the cyprinid Squalius aradensis and implications for conservation of the endemic freshwater fauna of southern Portugal. Mol Ecol 14:1939-1954.

Molina WF, Schmid M and Galetti Jr PM (1998) Heterochromatin and sex chromosomes in the Neotropical fish genus Leporinus (Characiformes, Anostomidae). Cytobios 94:141-149.

Palumbi SR (2003) Population genetics, demographic connectivity and the design of marine protected areas. Ecol Appl 13:146-158.

Reis SF, Pessoa LM and Strauss RE (1990) Application of sizefree canonical discriminant analysis to studies of geographic differentiation. Braz J Genet 13:509-520.

Revaldaves E, Renesto E and Machado MFPS (1997) Genetic variability of Prochilodus lineatus (Characiformes, Prochilodontidae) in the upper Paraná river. Braz J Genet 20:381388.

SAS Institute Inc (1988) SAS/STAT User's Guide, Release 6.03. Cary, NC.

Sekine ES, Prioli AJ, Prioli SMAP and Júlio Jr HF (2002) Genetic differentiation among populations of Pseudoplatystoma 
corruscans (Agassiz, 1829) (Osteichthyes, Pimelodidae) isolated by the Guaíra Falls in the Paraná River. Acta Scient 24:507-512.

Strauss RE and Bookstein FL (1982) The truss: Body form reconstructions in morphometrics. Syst Zool 3:113-135.

Sumner AT (1972) A simple technique for demonstrating centromeric heterochromatin. Exp Cell Res 75:304-306.
Turner BJ, Grudzien TA, Adkisson KP and Worrell RA (1985) Extensive chromosomal divergence within a single river ba$\sin$ in the goodeid fish, Ilyodon furcidens. Evolution 39:122-134.

Weir BS and Cockerham CC (1984) Estimating F-statistics for the analysis of population structure. Evolution 38:1358-1370.

Editor: Iracilda Sampaio

License information: This is an open-access article distributed under the terms of the Creative Commons Attribution License, which permits unrestricted use, distribution, and reproduction in any medium, provided the original work is properly cited. 